\title{
Rule of Lawyers: Liberalism and Colonial Judges in Nineteenth-Century Java
}

\author{
Sanne Ravensbergen
}

The landraad in nineteenth-century Java was a colonial law court that embodied and reflected a segregated colonial state, where separate courts and laws existed for different population groups. ${ }^{1}$ The landraad (plural: landraden) were regional law courts where only non-Europeans were tried and the courts were-increasing in number from 2 in 1800 to 89 in 1874-one of the most visible representations of Dutch colonial rule on the island. The courtrooms of the landraden were also highly pluralistic in nature since a majority of Javanese court members decided over the verdict together with the Dutch president by ballot, with Islamic and Chinese leaders providing advice on religious and local legal traditions. The pluralistic courtroom was, because of the encounters between and across the various powers, an arena where the colonial state, based on a 'dual rule'2 of Dutch and Javanese elites, gradually consolidated. ${ }^{3}$

In the course of the nineteenth century, the landraad increasingly received criticism from Dutch liberal lawyers, who argued that the colonial administrators who presided the landraden had to be replaced by

S. Ravensbergen $(\square)$

Leiden University, Leiden, The Netherlands

e-mail: s.ravensbergen@hum.leidenuniv.nl

(C) The Author(s) 2019

R. Koekkoek et al. (eds.), The Dutch Empire between Ideas and Practice, 1600-2000, Cambridge Imperial and Post-Colonial Studies Series, https://doi.org/10.1007/978-3-030-27516-7_8 
'independent' Dutch judges. Representing an influential constitutional liberalism as manifested in the Netherlands at the time, they focused on bringing their ideals of the separation of powers to the colonial courtroom. Or as M.C. Piepers, one of the most vocal nineteenth-century colonial jurists, assuredly wrote: 'there is also a rule of law in the Indies.' ${ }^{4}$ Their plea was heeded as, from 1869 onwards, jurists gradually started to replace the Dutch administrators (residents) as presidents of the landraden.

This chapter is a critical assessment of the vision of the rule of law as well as the actual practices of the liberal colonial jurists within the legal plural space of the landraad in Java. Historian Cees Fasseur has described the newly arriving colonial jurists as the ones who introduced enlightened ideas about law to the colony. He saw the introduction of a separate ('onafhankelijk'-independent) judiciary as exerting a positive influence 'that was fostered by a corps of highly trained Dutch officials even though they functioned within a colonial setting and framework.' 5 This argument has been repeated by other historians, but never critically reappraised. What exactly did change after 1869? How did the liberal colonial jurists think they were bringing the rule of law to Java? What were the consequences of them functioning within a colonial setting and framework? Which form of colonial liberalism did these jurists represent, in theory and in practice?

To answer these questions, I will study the liberal jurists as intermediate thinkers' of empire. Although the ideas of colonial jurists are often overlooked, as they were not the producers of high scholarship, they did contribute to an 'industry' of liberalism by expressing their views in societies, publishing pamphlets, writing in journals and newspapers, and arguing in Dutch parliament. ${ }^{6}$ By taking the developing ideas of the practicing colonial jurists seriously, it becomes possible to connect visions to jurispractice. ${ }^{7}$ Visions are never without context and the context, as I show in this chapter, impacts the vision as it developed. As Andrew Fitzmaurice has argued in a critique of the work of Lauren Benton who has strongly advocated the study of legal pluralism and jurispractice in colonial history, the danger of a too narrow focus on jurispractice is a negligence of the impact of intellectual ideas on local practices, and vice versa. $^{8}$

To fully acknowledge the local practices of plural legal spaces, moreover, all actors present in the studied plural space are important, especially in a courtroom where the Dutch judge often did not speak the language of the suspects and witnesses, could not make a verdict without 
the majority vote of the Javanese members, and was less familiar with the region than the other actors working at the court. The landraad, therefore, was a plural space where not only the Dutch president of the court, but also its Javanese court members and other local elites, practiced their ideas. All these intermediate thinkers interacting together formed and shaped a colonial legal culture in nineteenth-century Java.

Although the liberal jurists aimed at bringing the rule of law to Java, and often believed they did, I argue in this chapter that their perceptions of and engagements with the colonial reality proved them to be less straightforwardly 'liberal' in their actions, than assumed so far in the historiography. I show this by looking at their interactions with the local prosecutors ( $j a k s a)$ and Javanese court members in the pluralistic courts. I use an actor-focused approach and scrutinize practiced visions to demonstrate that liberal jurists, arriving in the colonial courtrooms during the decades after the reform of 1869 , safeguarded their own sphere of influence and were central to furthering colonial rule (Image 8.1).

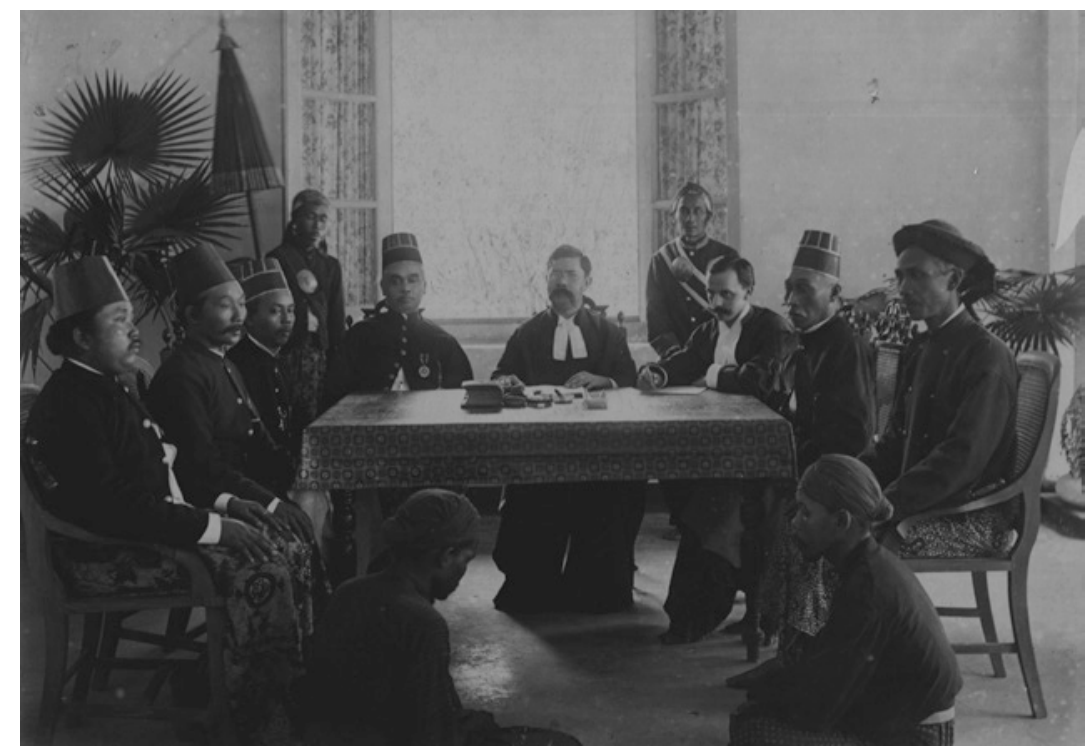

Image 8.1 Landraad session in Banyumas, ca. 1900. Leiden University Libraries Digital Collections [KITLV 119285] 


\section{RULE OF LAW IDEAS}

Dutch liberalism in the nineteenth century followed the continental liberal trajectory and focused on juridical constitutionalism. Contrary to French and German liberals, in the Netherlands the liberals were very influential in national politics, especially between 1848 and 1900 . Liberal leader, and constitutional law professor, Johan Rudolf Thorbecke would become a 'national hero' for having drafted the new constitution of 1848. Although impactful, Dutch nineteenth-century liberalism did not have specific great thinkers and; as historian Henk te Velde argues, Dutch liberalism was 'more a culture than an elaborate ideology. 9

Central to this constitutional liberal culture was the focus on the ideal of the rule of law, the rechtsstaat, which would be very apparent and influential for generations of liberals and especially liberal lawyers to come, who were part of the elitist men's club that constituted the liberal legal community. ${ }^{10}$ To liberal lawyers, the rechtstaat was seen as the ultimate ingredient to strong and just rule. The idea of the separation of powers had been circulating in the Netherlands since the end of the eighteenth century when there were various ideas about who had to be protected against whom. Eventually, in the Dutch context the separation of powers would be enforced mainly to prevent the administrative power from gaining too much influence over the judiciary. ${ }^{11}$ The Constitution of 1814 and its successors left no doubt as to the independence of the judiciary from administrative and legislative powers, although it was only in 1848 that the upper middle class, with its liberal judicial convictions, held enough power to organize a separate judiciary in the Netherlands. ${ }^{12}$ Even then, the legal system would remain a battleground, in particular regarding the aristocracy's influence on the provincial courts. ${ }^{13}$

Liberal ideas on law also reached the Dutch colonies, but the historiography of nineteenth-century Java devotes most attention to an economic liberalism that advocated the abolishment of the cultivation system (cultuurstelsel). Constitutional liberalism, however, was also apparent in the colonial context and manifested itself to a certain extent together with the economic reforms. After all, as we already know from British empire studies, the law was part of the broader colonial ideology and legitimacy of colonial empires. An extensive literature on British India in particular shows how, already in the eighteenth century, 
the colonial enterprise, and the legal system in particular, was promoted as a liberal mission to free the 'oppressed' local population from their 'despotic rulers.' ${ }^{\prime 4}$ Ideas about enlightened justice and the rule of law, however, clashed with the unequal and authoritarian colonial reality, and colonial law courts were an arena where the essentially unenlightened character of the colonial state was revealed. At the same time, colonial reality was more complicated than full-blown racism covered by some legal liberal patchwork. Enlightenment ideals about both the legal system and the civilizing mission were real, often incorporated in the legal system, and passionately defended by their proponents (all with their own interests and ideals) within the context of colonial reality. In British India, the expensive and large legal court system was more related to the mission of spreading 'civilization and justice' than to securing imperial needs. ${ }^{15}$ In practice, liberal reforms such as uniform legal codification did not contribute to fair legal procedures though, because notions of inequality between races were still central to the codes and legal practices. ${ }^{16}$ Over time, a colonial liberalism developed, legitimizing the politics of difference in the colonial context. ${ }^{17}$

A civilizing rhetoric was present in the Dutch colonies too, although it was less propagated as a colonial ideology nor exclusively labelled as liberal thinking at first. ${ }^{18}$ When from the second half of the nineteenth century liberal influence in the Netherlands increased, Western law was more and more promoted as a means of 'civilizing the Javanese people.' 19 Simultaneously, however, it was questioned whether the Javanese were 'ready' for Western laws, and the importance of applying Islamic or customary laws was discussed. The pluralistic courtroom of the landraad would remain in place, also because the colonizers soon realized that they could not administer justice without the information, networks, and prestige of the Javanese elite officials (priyayi) within the colonial policy of dual rule. Even though they successfully removed local laws from the codes, the institutional pluralistic character of the courts continued.

Despite these different circumstances in the colonial context and the particular nature of dual rule, the Dutch debate on the separation of powers did take place with regards to the colonial context. The judicial power in the hands of the resident was increasingly criticized by liberal lawyers claiming that it led to the abuse of power, while being fiercely defended by others. Intermediate Dutch thinkers such as private attorneys, residents, and members of judicial reform committees took part in this debate. 
At the start of the nineteenth century, the Asian Charter of 1803 had already proposed that administrative officials should no longer preside over the Javanese colonial courts. This call was not heeded. In 1839, a legal reform committee presided by the Dutch jurist C.J. Scholten van Oud-Haarlem also pleaded to install separate presidents at the landraden to foster the independence of the judicial system. ${ }^{20}$ Most conservatives, and in particular State Secretary J.C. Baud were opposing separate landraad presidents though. From Baud's perspective, it was exactly the concentration of power in the hands of one person in a residency that had convincingly established the colonial authority. He preferred everything to remain as it was, in particular to ensure that the colonial government could continue to reap the benefits of the cultivation system. ${ }^{21}$

The call for independent, judicial, landraad presidents was reiterated during the following decades, predominantly by liberal lawyers who denounced the entanglement of interests and abuses of power. Especially private attorney Charles Jean François Mirandolle believed that there would be no greater favour to offer to Java than a separation of administrative and judicial powers. Mirandolle (1827-1884) was born in Paramaribo, Surinam, trained as a lawyer in the Netherlands and owned a law firm in Java from 1853 to 1864 . After his return to the Netherlands, he became a member of Dutch parliament. In his articles and letters, Mirandolle refuted the much-heard argument among the Dutch that 'the Oriental' in nature would prefer a unification of government powers. According to Mirandolle, this was not an argument to allow injustice to exist. He argued that the dependent judge was in contradiction with the principles of justice, so this had to be changed anyway. ${ }^{22}$

In response to an inquiry by the new Attorney General W. Rappard in 1860 who expressed his concern about the quality of the case files of the regional law courts, the few Dutch judges present in Java mainly identified the lack of time and knowledge among residents. ${ }^{23}$ Mirandolle, however, when asked for his view, emphasized the fact that the real issue here was that residents would always put their political interests first, and that this was especially detrimental to criminal law. According to him, Dutch residents only had two aims when administering criminal justice in the colony. Their main goal was to get the suspect declared guilty during a landraad session. Therefore, he maintained, they often 
neglected to investigate whether the accused was actually guilty at all. Second, the confession of the accused was considered the most important proof. To obtain a confession 'often moral, and sometimes personal torture' was applied. This could include flogging, sleep deprivation or the torture of relatives. Moreover, bribing and punishing witnesses was not uncommon. ${ }^{24}$

Mirandolle and others published their claims in newspapers and journals, publishing pressing articles that demanded reform. ${ }^{25}$ In 1863 attorney J. van Gennep and notary J.R. Kleijn established the Indies' Weekly Journal of Law (Indisch Weekblad van het Recht) which declared that its aim was the denunciation of abuse: 'A constantly open opportunity to report facts and existing abuses will be a forceful instrument, not only to repel but also to prevent arbitrariness. ${ }^{26}$ In the first editions of the journal, articles were devoted to the rattan punishment and why it had to be abolished, the police magistracy, and the subject of the resident as landraad president.

After much debate, the judicial landraad president was introduced in Java in 1869. The reform was possible at that moment due to the increased power of the liberals in the Netherlands, who targeted the cultivation system and related this to the absence of a separation of powers in the colony. But it was also possible because the residents themselves did not entirely oppose the plan any longer. Due to their increasing workload as the colonial bureaucracy expanded, the idea of someone else taking over this considerable task seemed rather appealing. The residents who responded to the inquiry by attorney general Rappard did not mention any problems regarding criminal law practice, but emphasized the difficulties with civil law cases on a regional level and therefore expressed some willingness to accept the appointment of judicial officials in the residencies. ${ }^{27}$

\section{The Arrival of Jurists in the Colonial Courtroom}

Although the turning point is set in 1869 , in reality the arrival of jurists in the residencies would be gradual. Ten years after the reform, there were still thirty-eight landraden (out of 89) in Java headed by the resident. ${ }^{28}$ Only in 1901 all landraden in Java were presided over by separate judicial officials. The police magistracy would remain in the hands of the resident until 1914, and on some of the other islands the resident would continue to preside the landraad until decolonization. ${ }^{29}$ 
The colonial jurists were educated at a Dutch university and their training was completely focused on Dutch law, followed by a separate colonial exam with a preparation time of around one to two years. The limited training consisted of an introduction in the geography, ethnology, and languages (Malay or Javanese) of the Indonesian archipelago, Islamic law and other local customs and laws, and the colonial legislation and regulations. The courses offered as preparation for the exams were very theoretical, with little training in local languages or legal practices in preparation of the future profession as colonial judge. Courses in Islamic law were for the most part of the nineteenth century based on a rather random selection of Islamic texts, while local laws and customs were described as 'anomalies.' It was never considered to appoint Javanese lecturers for language or legal training. ${ }^{30}$

It also happened regularly that someone without having done the exam was appointed as a colonial judicial official. Lawyers who had worked for at least four years as private attorneys in the Netherlands Indies were exempt from the exam and could be appointed as colonial judge. And in times of a shortage of lawyers, fresh graduates were even appointed. After the reform of 1869, so many new judges were needed that in 1873 and 1874 no less than 42 jurists were recruited who had only taken a lighter exam in the colonial legislation and regulations and elementary knowledge of Javanese. ${ }^{31}$

Both administrative and judicial officials in colonial service were expected to be raised in a 'civilized European' environment while knowledge of and feeling with 'the East' was deemed important as well. ${ }^{32}$ Commotion ensued when the Indo-European C.J. van HaastertEuropean by law but with a Javanese mother-was listed for the office of colonial official in 1847. He held a doctorate in law from Leiden University in the Netherlands and had returned to Java. Although considered qualified, according to Governor General Rochussen he would be unable to exercise enough authority over the local population and Javanese elite officials (priyayi), and was therefore ineligible for a government position. After protest from other colonial officials though, many of whom had Indonesian blood themselves or who had Indo-European children by their Javanese concubine, it was decided that anyone who had passed the colonial exam was allowed to work as an official in the Netherlands Indies. ${ }^{33}$

Although formally everyone, except for Foreign Orientals (Chinese and Arabs) and Western Foreigners (who were only allowed in engineering positions), was allowed to take up the position of administrative or judicial 
official, in practice in the nineteenth-century Indonesians were never appointed at the Dutch side of the civil service, certainly not as resident or judge. In the entire century, only one Indonesian, Raden Mas Ismangoen Danoe Winoto, took and passed, with very good results, the administrative exam (grootambtenaarsexamen) in the Netherlands, but he was denied a position at the colonial civil service. ${ }^{34}$ The first Indonesian landraad president Moehamad Hamid was only appointed in $1925 .{ }^{35}$

The administrative and judicial colonial officials were predominantly Dutch, but they came from different social backgrounds. Whereas the judicial officials held a university degree, the administrative officials were often trained at the colonial institution in Delft (and later Leiden). The difference with the less practical and more theoretical jurists led to extra tensions when the jurists arrived in the Javanese residencies to preside over the landraden after 1869. Administrative official Van der Kemp wrote in 1885 that the jurists had been acting arrogantly and dismissively, and he argued that the jurists' bookish view of the world was not appropriate in a colonial situation. He denounced the beliefs of jurists such as A.J. Immink and Piepers-both of whom served first as landraad judge and thereafter as a member of the Supreme Court-neither of whom accorded much value to a knowledge of local languages, but instead emphasized the importance of following the colonial law codes closely. ${ }^{36}$

The jurist A.J. Immink, appointed landraad president in Surabaya in 1876 , on his turn was very unhappy with the way he was welcomed by the resident. ${ }^{37} \mathrm{He}$ argued that the colonial civil service was 'far from content finding a kind of obstructer next to them, to whom the native could turn for protection against injustice and arbitrariness.' He published a pamphlet in which he discussed a few examples to show that the administrative officials were opposing the new judicial landraad presidents.

Fierce in particular was the conflict of landraad judge J. de Haas with the assistant resident of Semarang, F.W.H. van Straaten in 1876. Van Straaten had decided to preside over a court case when judge De Haas had fallen ill. Although De Haas wanted to continue presiding over the landraad sessions until his deputy arrived, in two opium cases the assistant resident decided he would himself preside instead. The assistant resident even wrote to the Javanese court members and advisors that they were not allowed to act in landraad sessions presided by judge De Haas. This dispute became the talk of town and on the first day of the court session, when De Haas arrived to act as a judge despite his illness, 
a crowd gathered in front of the landraad. The chief jaksa, Javanese members, and the Chinese officer were present, but then a messenger announced that the landraad judge had to leave the room, because assistant resident Van Straaten was to replace him. He also ordered the chief jaksa not to carry out his functions. This put the chief jaksa in a difficult position, since he was formally working on behalf of the assistant resident, but within the courtroom he was closely cooperating with the landraad judge. This violation of the official regulations caused such a dilemma for the chief jaksa that he pretended to faint in court, causing the session to be cancelled. The other jaksas were nowhere to be found and the court session could not proceed. Of this incident, Immink wrote 'whether the illness of the chief jaksa was truly severe has not been proven. It is certain though, that he and those in a similar position, had found themselves in a difficult position. ... A sudden ailment was certainly a useful instrument to escape from this difficulty. 38

Another example mentioned in Immink's pamphlet was a conflict over seating arrangements at an official gathering with priyayi, where the landraad president of Kediri M.C. Piepers to his 'perplexity' had not been seated right next to Resident J.H. Hagen, but one seat away. After a heated correspondence between Piepers and the resident, the former was transferred to Tuban. According to Immink, this case was especially harmful because it was important to communicate to the Javanese chiefs 'which rank within official Javanese society was given to the-almost entirely newly established-independent law court.' In other words, this conflict could have meant a degradation of the status of the landraad. Also, that the landraad judge could be dismissed by the government was an encroachment of his 'independent' position. Thus, according to Immink, judges in the Netherlands Indies were still 'legally fully dependent' and no measures had been taken to alter this. ${ }^{39}$

Despite their lack of interest in local legal traditions, the liberal jurists did strive for certain reforms in favour of the Javanese population. The number of acquittals by the landraden seems to have increased, pointing at a more critical assessment of legal evidence, and jurists also actively tried to shorten the period of pretrial detentions. ${ }^{40}$ As the colonial jurists became a common figure in the residency, however, their interaction with local circumstances and actors, started to influence their vision on the rule of law in the colonial context. First of all, they functioned within the segregated legal system where the unequal features would hardly be resolved. Marieke Bloembergen has argued, how, over the course of 
the nineteenth and early twentieth centuries, most officials and jurists supported the segregated system either from a conservative or a liberal perspective. Or-and this was often the case-from a pragmatic policy perspective that never chose between the ideal of unification or dualism. ${ }^{41}$ Wim van den Doel describes how liberal thinking by Dutch colonizers was often combined with 'paternalistic acting. ${ }^{42}$

On a micro level, when we study the daily practices of liberal judges at the landraad, they encountered another and complicating context within the segregated legal system: a pluralistic courtroom where local elites were seated as court members and acted as prosecutor ( $j a k s a)$.

\section{Dutch AND JaVANESE JUdGeS}

Although they often did not mention it in their letters, articles, and memoirs, the Dutch landraad presidents were not single judges. A landraad verdict was always decided by ballot and the Javanese court members held a majority of the votes. But, when in the 1850s and 1860s the dependent position of the landraad presidents was heavily discussed, the position of the Javanese court members was not under discussion. The separation of the administrative and judicial powers through the introduction of the judicial landraad president in 1869 had been advocated by jurists as an important reform, even though in fact, only one official had been replaced in an environment where no further separation of powers would take place. And the colonial judges would, also after arrival, not strive for independent Javanese judges in the landraad. The Javanese court members would remain in their administrative appointments and were involved in both the preliminary police investigations and the judicial administration. Moreover, the nomination of new Javanese court members to the landraad was still arranged by the resident and not by the landraad president. ${ }^{43}$

The Asian Charter of 1803 had recommended the appointment of both independent Dutch and independent Javanese court members to the landraden. The advice had been of no avail. In 1869, with the introduction of the judicial landraad presidents, this was not even on the table. During the entire decision-making process in 1869, no one mentioned that the other members in the landraad, the Javanese judges, would still not meet the standards of what was then described as the ideal of a 'civilized nation'; after all, the Javanese members - with the right to vote on the verdict and in the position of judge-executed administrative functions along with their judicial ones, as the resident did. 
Although the Javanese members were mentioned obliquely in the discussions, and any proposals to abolish the Javanese members altogether and introduce a European single judge was firmly opposed, no one suggested even once that the Javanese members should be independent. Mirandolle was the only one who in the 1860s wrote about the relations between the Javanese members and the European president. Interestingly enough, he was convinced that the Javanese members would actually regain their independence once judicial officials were presiding over the landraad instead of the resident, since they had a more complex and submissive relationship with the latter. ${ }^{44}$

Even if the Javanese members were themselves the target or victim of a crime, and were consequently personally involved in a case as one of the parties, they were not necessarily replaced as court members during the court session. After the revolt in Cilegon (West Java) in 1888, for example, the court consisted of local priyayi who came from the region and were related to the victims. The patih (right hand of the regent) Mas Pennah had been a target and had escaped because he had not been at home during the outburst of violence. Nonetheless, he was appointed the leader of the preliminary investigations and he was seated in court as a voting member. Other members of the court had also been closely involved, and the cousin of one of the court members, Entol Goenadaja, the wedono (district head) of Cilegon, had been one of the victims. ${ }^{45}$

During the 1880s, the Indies Organisation for Jurists (Indische Juristenvereeniging) was established, in which possible reforms of the colonial legal system were discussed. In practice, this organization mainly focused on the protection of the colonial judges' own position regarding topics of remuneration and protection against impeachment, and sometimes the police magistracy that was still in the hands of the resident. After only a few years, the organization stopped actively meeting. ${ }^{46}$ Through judicial journals such as the Weekly Journal of Law and the Indies Journal of Law, jurists would still share information in the form of verdicts and articles. Quite soon though, the Weekly Journal would lose most of its liberal fighting spirit.

In none of the discussions held among Dutch colonial jurists were the Javanese priyayi consulted for advice. Legal education for them was also not arranged and they were mainly deemed important for their knowledge of the local circumstances. Jurist H.L.E. De Waal pleaded for single European landraad judges, but he considered it important that Javanese members remain seated in the pluralistic courts as advisors. For 
De Waal, the Javanese judges were 'unsuitable' as judges but remained essential as reservoirs of local knowledge. As he noted: 'The native is not developed enough to be able to accurately decide over somewhat complicated cases, and his character and his awe for authority make him unsuitable for the independent position of impartial judge. On the other hand, his advice on the assessment of factual or local circumstances are of immeasurable value. ${ }^{37}$

It was only almost twenty years later, during a general meeting of the Indische Genootschap in 1900, that a proposal for reform provided by a prominent Javanese regent was mentioned. During that meeting, D. Mounier first proposed removing the Javanese members from the landraad altogether. He presented a number of arguments that incongruously veered between their being too dependent on the president and oldest member, and their being inclined to oppose the judicial president without good reason. ${ }^{48}$ He suggested removing the Javanese members from the courtroom temporarily, but he was also in favour of a proposal of the regent of Demak, Raden Mas Adipatih Ario Hadiningrat, ${ }^{49}$ who advocated for a Javanese judicial corps that would function independently from the administrative Javanese officials. ${ }^{50}$

Hadiningrat had been chief jaksa in Pekalongan before he became the regent of Demak. He published his first article in a colonial journal in the early 1870s and would continue writing and corresponding about necessary (mainly educational) reforms to improve the quality of the colonial civil service. He and his family-his father had arranged a Dutch tutor for his four sons, and Raden Adjeng Kartini was his niecewere very invested in educational issues. Hadiningrat was loyal to the colonial government but critical-he would be the first president of the Regentenbond, and at the end of the nineteenth century some appreciation for his proposals would emerge. ${ }^{51}$

Hadiningrat was essentially the only intermediate thinker in colonial debates who presented a similar argument for the 'independent' position of both the Dutch and Javanese judges. In 1898, he wrote an article in which he proposed several reforms. He had already proposed these reforms in a government report in 1876, but they were dismissed by his Dutch supervisors in the colonial civil service. One of his main ideas was the modelling of the 'native branch' of the colonial government after the Dutch branch. Important to this model was the introduction of a 'separate native judicial power' that was organized 'separately from the branch that deals with administrative matters.' This separate corps of indigenous 
judicial officials had to be incorporated in the corps of Dutch judicial officials. ${ }^{52}$

Hadiningrat's suggestion of introducing separate Javanese judges, was again ignored; only his plea for Western education for priyayi was welcomed. Parliamentarian C. Th. Van Deventer, one of the leading figures of the Ethical Policy movement, responded to Mounier's reference to Hadiningrat's idea only by saying that it would be a 'major political mistake' and a 'dangerous experiment' to remove the Javanese members from the pluralistic courts. He blamed the colonial government for having neglected to bring the Javanese to a more 'developed' level, and he wanted action to be taken on this matter as soon as possible. ${ }^{53}$ Jurist Maclaine Pont also did not want to exclude the Javanese members from the court sessions, mainly because of their knowledge of the land: 'They [the local members] are also useful, because the presidents are, especially at the start of their career, sometimes burdened by their embellished erudition, which can quite get in their way, and then it is often the common sense of the Landraad members that prevents them from curious verdicts.' He also pleaded to educate the Javanese aristocratic sons: 'Because law is not that difficult, and it is perfectly possible to be studied by a well-developed Javanese. ${ }^{54}$ The first law school for Indonesians was opened in 1908.

In any case, the Javanese administrative officials continued to be appointed as law court members. In 1916, landraad judge Boekhoudt emphasized the importance of the views and knowledge of the Javanese members in criminal cases: 'Without the forceful cooperation of their side, it is impossible for a young jurist to successfully bring a case to a good end. ${ }^{55}$ J. Sibenius Trip similarly emphasized that Javanese members had prevented him, as a judge (1859-1865), from wrong verdicts, as he wrote in the Indies' Weekly Journal of Law in 1905. He described how the sentence 'Bagaimana toewan poenja soeka' ('As you wish, Sir') articulated by Javanese members who followed the views of the Dutch judge during the deliberations, had to be understood as a sign that the priyayi knew more about the case and that it was best to follow their advice. ${ }^{56}$

Yet, the colonial mind of all these colonial jurists could not comprehend a similar expectation of 'independence' from both Dutch and Javanese law court members. Whereas the liberal jurists had been adamant in their belief that the Dutch landraad presidents had to be judicial officials with no administrative responsibilities, they did not propose the same reform for the Javanese court members (Image 8.2). 


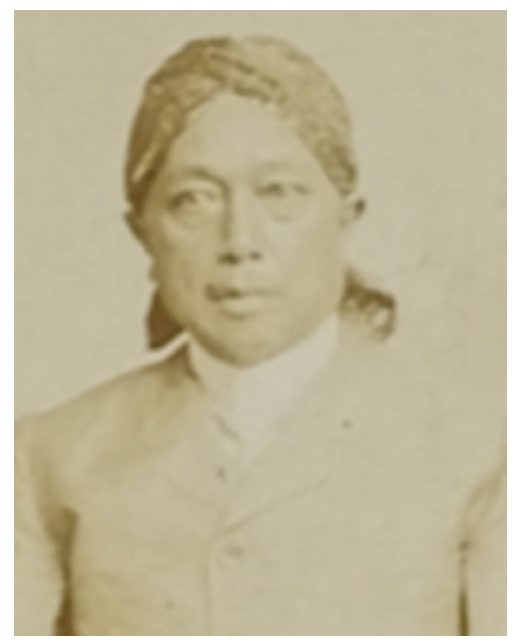

Image 8.2 Hadiningrat in 1911. Leiden University Libraries Digital Collections [KITLV 15499]

\section{JUDGE AND JAKSA}

The most direct contact the landraad presidents had was with the Javanese public prosecutors; the jaksas. During pluralistic court sessions, the jaksas functioned both as public prosecutors and as translators. In the Netherlands Indies, there was no department of justice until 1870, and the attorney general was the head of the European public prosecutors, not the jaksas who received their orders directly from the resident. This meant that the resident was not only the landraad judge, but also the head of the police and supervisor of the prosecutor. Also, after the introduction of the judicial landraad presidents, the resident remained the direct supervisor of the jaksas. ${ }^{57}$ We have seen above that this could lead to complicated situations in the case of the chief jaksa who pretended to faint in the courtroom when he found himself in the middle of a conflict between the resident and judge.

Remarkably, at the end of the nineteenth century, most liberal jurists still preferred the situation in which the jaksa remained under the resident rather than the attorney general. Although as defenders of the trias politica they fought fiercely for the introduction of independent 
landraad judges, they were not so principled regarding the position of the jaksa. Generally, they agreed on a close supervision of the jaksas by the resident.

In 1885, the jurist Abendanon proved an exception when he suggested during a meeting of the Indies' Jurists Association to subordinate the jaksas to the attorney general and to be supervised by the European public prosecutor of the Council of Justice; the only person to vote for this plan was Abendanon himself. The only majority vote was for improved career prospects and a corresponding raise in salary within the jaksa ranks. Most jurists expected much from better-educated jaksas. ${ }^{58}$

During the meeting a few jurists even pleaded for the introduction of 'European jaksas,' European prosecutors who would replace the Javanese jaksas in the pluralistic courts. This proposal was repudiated, though, as an idea from other-worldly colonial jurists. Indirectly affirming the importance of the jaksas, administrative official Van der Kemp commented cynically: 'Ah, well, of course! If one would have such attributes [European prosecutors], then, administering justice over the Natives by scholars unfamiliar with the people will not be that hard. ${ }^{59}$ Altogether, the position of the jaksas would not change and they remained outside the Public Prosecution Service.

In 1884, jurist W.A.J. Van Davelaar wrote in a judicial handbook that it was impossible to give jaksas responsibilities comparable to those of European prosecutors. The Public Prosecution Service had to be independent, and according to Van Davelaar the jaksas could not possibly meet this requirement. First, because they were often lower ranked than the Javanese members of the law court-if these were regent or patihand they would therefore tend to follow their orders instead of acting independently. Second, the jaksas did not have the judicial knowledge necessary to be able to keep standing before the European court president. ${ }^{60}$ Thanks to these two criticisms, the position of the jaksa was increasingly stripped of its responsibilities over the course of the nineteenth century. Most tellingly, the jaksas were stripped of their responsibility for drafting indictments (acte van beschuldiging), which became the responsibility of the landraad judge.

A first step in this reform was that it was decided in 1885 that the document of reference (acte van verwijzing; document that decided by which law court a case would be administered) would from then on be drafted by the landraad judge instead of the resident. ${ }^{61}$ The division of labour was that the landraad judge drafted the document of reference 
whereas the jaksa drafted the indictment. The accusations made in the indictment had to be restricted to the boundaries set by the document of reference. ${ }^{62}$ In practice, the landraad judge also checked the indictment written by the jaksa, because it was said the jaksas could not draft indictments on their own. According to the Native Regulations, the indictment had to include the facts that were seen as proven by the prosecutor and that were the basis of the accusation. Instead, the indictment quite often was more a summary of the statements given by the suspect and witnesses during interrogations, followed by the charge; thus the offence for which the defendant was being charged remained unclear, as was any determination, for example, of whether the crime that had been committed was premeditated or not. ${ }^{63}$ In 1898 , indictments were even completely taken away from the jaksa by abolishing the indictment altogether, and keeping the document of reference (drafted by the landraad judge) and formally introducing this document as the indictment. ${ }^{64}$

The road to these reforms was characterized by technical, judicial discussions, in which Piepers in particular took a very legalistic approach; the act of reference had to be correct, and would otherwise be declared illegitimate. He was opposed by Attorney General W. de Gelder, who wanted to deal with this in a more lenient manner. Apart from this technical debate, all jurists generally agreed that the indictment had to be abolished and that the landraad judge had to continue writing the document of reference. ${ }^{65}$ This marginalized the role of the jaksa.

The landraad judges essentially came to fulfil the positions of both judge and prosecutor. The young landraad President Cornelis (Kees) Star Nauta Carsten noticed this and wrote about it to his father (himself a jurist) in 1920, not long after his first appointment to a landraad. He described how he received cases from the administrative government and decided whether they had been investigated sufficiently. If there was enough proof, he would immediately draft the indictment: 'So, I am not only the president of a law court with two native members, but also at the same time more or less the Public Prosecution Service.' He did not think very highly of the jaksa, of whom he wrote 'there is a native with the title of "native public prosecutor," or jaksa, but his responsibility exists solely of interrogating the suspect, who has been brought to the capital of the residency, and is kept there in prison. Later, during the court session, he [the jaksa] is not much more than a translator.' ${ }^{\text {'66 }}$

Altogether, it is clear that the liberal jurists were not interested in advocating a more independent position for the Javanese prosecutors. 
The jaksas continued to be subordinated to the resident and regent, instead of the attorney general as was the practice in the Netherlands. Moreover, the landraad judges were now even fulfilling the position of prosecutor and judge. The aim was no longer the rule of law-as it had been when striving for the independent landraad judges-but rather the establishment of a rule of lawyers, instead. Dutch jurists were so convinced of their moral superiority over the Javanese that they thought it defensible to unite several powers in their own position. This resulted partly from a desire for more influence than the residents, but it was also a paternalistic pursuit of better criminal justice for the Javanese. It was deemed impossible from the colonizer's perspective that jaksas might be able to faithfully and sufficiently exercise the responsibilities of a public prosecutor, even if they had been educated in judicial procedures and drafting indictments.

\section{Conclusion: Liberal Rhetoric, Colonial Reality}

Dutch constitutional liberalism with its focus on a separate judiciary reached colonial Java in the 1860s in full force. Even though the new arriving Dutch judges in Java seemed to have improved the legal position of the Javanese population somewhat by following the prescribed rules and procedures more closely than the residents, they were also quick to manoeuver themselves into a powerful position.

The colonial judges did not continue their pursuit of an entirely independent judiciary in the colonies by making themselves responsible for indictments, instead of the jaksa, and not promoting the idea of having independent Javanese judges in the landraad. By doing so, the colonial liberal jurists manifested themselves as intermediate actors who shaped a Dutch colonial liberalism. Javanese intermediate thinkers were hardly heard by the colonizers and not included in the colonial debates on legal reform. It is only through the silent protest of the fainted chief jaksa, and the persistent writings of regent Hadiningrat who argued in favour of separate Javanese judges, that we gain insights into the agency and ideas of the Javanese priyayi within the colonial legal system.

While Dutch jurists in colonial Java had increasingly criticized those features of the colonial state that went against their ideal of the rule of law, they were simultaneously essential to maintaining the unjust colonial state and giving legal grounds to the politics of difference. This chapter has shown that if we had only focused on the ideas as expressed by the 
jurists in their writings, we would have detected the theoretical emphasis on the rule of law. The reality of the courtroom, however, shows that the belief in a balance of powers was made subsidiary to the belief in the superior Western legal mind. Legal education in the Netherlands and the colonial system in Java moulded a colonial mind and shaped colonial liberalism. After arriving in the colonial courtroom, Dutch jurists safeguarded their own sphere of influence and further confirmed the colonial rule. Instead of a rule of law, they established a rule of lawyers.

\section{Notes}

1. I would like to thank the editors, Alicia Schrikker and the other participants of the Visions of Dutch Empire conference for their comments on earlier drafts of this chapter. The research for this chapter was financed by the Netherlands Organisation for Scientific Research (NWO).

2. Historians Wim van den Doel and Heather Sutherland each analysed one of the two branches of the dual system. Hubrecht W. van den Doel, De Stille Macht: Het Europese Binnenlands Bestuur op Java en Madoera 1808-1942 (Amsterdam: Bert Bakker, 1994); Heather A. Sutherland, The Making of a Bureaucratic Elite: The Colonial Transformation of the Javanese Priyayi (Singapore: Heinemann, 1979). For a dynamic approach of the encounters between the Dutch and Javanese side of the colonial civil service in the nineteenth century see Onghokham, The Residency of Madiun: Priyayi and Peasant in the Nineteenth Century ( $\mathrm{PhD}$ dissertation, New Haven: Yale University, 1975); ibid., 'Social Change in Madium (East Java) During the Nineteenth Century: Taxes and Its Influence on Landholding,' in Proceedings Seventh IAHA Conference, 22-26 August 1977, Bangkok l (1977): 616-641.

3. Sanne Ravensbergen, 'Anchors of Colonial Rule: Pluralistic Courts in Java, c.1803-1848,' Itinerario 42, no. 2 (2018): 238-255.

4. M.C. Piepers, Macht tegen recht: de vervolging der justitie in Nederlandsch Indie (Batavia: Van Dorp \& Co., 1884), 132, 153; 'Het atavisme der O.I. Compagnie en van het kultuurstelsel,' Tijdschrift voor NederlandschIndië 2 (1884): 401-437.

5. Cees Fasseur, 'Violence and Dutch Rule in Mid-Nineteenth Century Java,' Paper Presented at the Workshop Violence in Indonesia: Its Historical Roots and Contemporary Manifestations, Leiden (2000), 10-11.

6. For the idea of intermediate thoughts and empire, see Emma Rothschild, 'Language and Empire, c.1800,' Historical Research 78 (2005): 208-229, 223-226; Emma Rothschild, The Inner Lives of Empire: An EighteenthCentury History (Princeton: Princeton University Press, 2011). 
7. Lauren Benton, Law and Colonial Cultures: Legal Regimes in World History, 1400-1900 (Cambridge University Press, 2002); Lauren Benton, 'International Legal Theory: Made in Empire: Finding the History of International Law in Imperial Locations,' Leiden Journal of International Law 31 (2018): 473-478.

8. Andrew Fitzmaurice, 'The Dutch Empire in Intellectual History,' $B M G N$ Low Countries Historical Review 132, no. 2 (2017): 107-108. See also Alicia Schrikker's chapter in this volume.

9. Henk te Velde, 'The Organization of Liberty: Dutch Liberalism as a Case of the History of European Constitutional Liberalism,' European Journal of Political Theory 7, no. 1: 66-68. For an overview of the development of liberalism in the Netherlands: Siep Stuurman, Wacht op onze daden: het liberalisme en de vernieuwing van de Nederlandse staat (Amsterdam: Bakker, 1992).

10. Henk te Velde, 'The Organization of Liberty,' 68.

11. M.T. Oosterhagen, Machtenscheiding: een onderzoek naar de rol van Machtenscheidingstheorieën. In oudere Nederlandse constituties, 1798-1848 (Deventer: Gouda Quint, 2000), 124-125.

12. Oosterhagen, Machtenscheiding, 180, 222.

13. Roel Pieterman, De plaats van de rechter in Nederland 1813-1920: Politiek juridische ideeënstrijdover de scheiding van machten in de staat (Arnhem: Gouda Quint, 1990), 79-81.

14. Martin Wiener, An Empire on Trial: Race, Murder, and Justice Under British Rule, 1870-1935 (New York etc.: Cambridge University Press, 2009), 1; Thomas R. Metcalf, Ideologies of the Raj: The New Cambridge History of India III, no. 4 (Cambridge etc.: Cambridge University Press, 1994), 27.

15. Wiener, An Empire on Trial, 4-6.

16. Elizabeth Kolsky, Colonial Justice in British India: White Violence and the Rule of Law (Cambridge etc.: Cambridge University Press, 2010), 11.

17. See for example: Marilyn Lake, 'Equality and Exclusion: The Racial Constitution of Colonial Liberalism,' Thesis Eleven 95, no. 1 (2008): 20-32; Uday Singh Mehta, 'Liberal Strategies of Exclusion,' in Tensions of Empire: Colonial Cultures in a Bourgeois World, ed. Fredrick Cooper and Ann Stoler, 59-86 (Berkeley etc.: University of California Press, 1997); Metcalf, Ideologies of the Raj, 28-65; and Jennifer Pitts, A Turn to Empire the Rise of Imperial Liberalism in Britain and France (Princeton: Princeton University Press, 2009).

18. Alicia Schrikker, 'Restoration in Java 1815-1830,' Low Countries Historical Review (BMGN) 130, no. 4 (2015): 132-144.

19. See for example: G.D. Willinck, Desa-politie en justitie (SemarangCheribon: A. Bisschop, 1897), 1-2. 
20. A.J. Immink, De Regterlijke Organisatie van Nederlandsch-Indië (The Hague: Stemberg, 1882), 4-7.

21. Immink, De Regterlijke organisatie, 9.

22. Dutch National Archives (NL-HaNA), The Hague, 2.10.02 MvK 18501900, Vb. February 7, 1867, no. 8. Letter from Mirandolle to Attorney General Rappard. Biography: www.parlement.com (last accessed 13 April 2019).

23. NL-HaNA, 2.10.02 MvK 1850-1900, Vb. February 7, 1867, no. 8. Letter from circuit court judge J. Sibenius Trip to attorney general Rappard. Rembang, November 24, 1862; Letter from circuit court judge W. Diemont to attorney general Rappard. Batavia, December 27, 1862.

24. NL-HaNA, 2.10.02 MvK 1850-1900, Vb. February 7, 1867, no. 8. Letter from Mirandolle to Attorney General Rappard.

25. See for example: C.J.F. Mirandolle, 'De hervorming der rechtsbedeeling in Indie II: De Landraden,' Tijdschrift voor Nederlandsch-Indie 1 (1867): 163174; C.J.F. Mirandolle, 'De hervorming der rechtsbedeeling in Indie I: De Policie-rol,' Tijdschrift voor Nederlandsch-Indie 1 (1867): 14-24.

26. [Editors], Indisch Weekblad van het Recht 1 (4-7-1863): 1-3.

27. NL-HaNA, 2.10.02 MvK 1850-1900, Vb. February 7, 1867, no. 8. Letters from the residents: Resident of Kedu, G.M. van de Graaff. Magelang, March 11, 1863; Resident O. van Rees of Surabaya, March 4, 1863; Resident Tijzelaar of Rembang. Rembang, March 24, 1863.

28. H.L.E. de Waal, De invloed der kolonisatie op het inlandsche recht in Nederlandsch Oost Indië (Haarlem: G. Van den Berg, 1880), 104.

29. NL-HaNA, 2.10.02 MvK 1850-1900, Vb. December 17, 1906, no. 19.

30. Cees Fasseur, De Indologen: Ambtenaren voor de Oost 1825-1950 (Amsterdam: Bakker, 2003), 149-150, 242-246.

31. Fasseur, De Indologen, 238, 242, 248. In the early twentieth century a similar shortage occurred, and between 1904 and 1922 the large number of 146 jurists were appointed after three years of 'desk service' in the colony.

32. Fasseur, De Indologen, 200.

33. Fasseur, De Indologen, 117; Ann Stoler, Along the Archival Grain: Epistemic Anxieties and Colonial Common Sense (Princeton etc.: Princeton University Press, 2009), 57-72.

34. Fasseur, De Indologen, 288-289. He would work as an inspector of indigenous education, and was discriminated against by his colleagues.

35. A.W.H. Massier, Van 'recht' naar 'bukum': Indonesische juristen en hun taal, 1915-2000 (PhD dissertation, Leiden University, 2003) [transl. and published: The Voice of the Law in Transition: Indonesianjurists and Their Languages, 1915-2000 (Leiden: KITLV Press, 2008)], 78, 105 (footnote 238). 
36. P.H. van der Kemp, 'De rechterlijke macht in haar streven naar onafhankelijkheid en in haren afkeervan het BB,' De Indische Gids l (1885): $445-481$.

37. A.J. Immink, Iets over de tegenwoordige afhankelijkheid van de Nederlandsch Indische rechterlijke ambtenaren (Amsterdam: De Bussy, 1880); Cees Fasseur, 'Immink, Adrianus Johannes (1838-1914),' in Biografisch Woordenboek van Nederland. http://resources.huygens.knaw. $\mathrm{nl}$ /bwn1880-2000/lemmata/bwn4/immink.

38. Immink, Iets over de tegenwoordige afhankelijkheid, 19. The name of the chief jaksa is not mentioned in the article.

39. Immink, Iets over de tegenwoordige afhankelijkheid, 3-5, 14. According to article 94 of the 1854 Colonial Constitution (Regeeringsreglement), the Supreme Court members were unimpeachable, but this did not apply to other judicial officials.

40. Sanne Ravensbergen, Courtrooms of Conflict: Criminal Law, Local Elites and Legal Pluralities in Colonial Java (PhD dissertation, Leiden University, 2018), 270-276.

41. Marieke Bloembergen, De koloniale vertoning: Nederland en Indië op de wereldtentoonstellingen (1880-1931) (Amsterdam: Wereldbibliotheek, 2002), 58.

42. Van den Doel, De Stille Macht, 103.

43. Piepers, Macht tegen recht, 355.

44. Mirandolle, 'De hervorming der rechtsbedeeling in Indie II: De Landraden,' 163-174.

45. Achmad Djajadiningrat, Herinneringen van Pangeran Aria Achmad Djajadiningrat (Amsterdam etc.: Kolff, 1936), 38, 52.

46. The Indies Organisation for Jurists (Indische Juristenvereeniging) was re-established in 1913.

47. De Waal, De invloed der kolonisatie op het inlandsche recht, 105-106.

48. D. Mounier, 'Iets over de Landraadvoorzitters op Java en Madoera,' Indisch Genootschap, algemene vergadering (27-3-1900): 141-146, 146.

49. The minutes say Adiningrat, but it was Hadiningrat who wrote a proposal for the improvement of the education of Javanese priyayi.

50. Mounier, 'Iets over de Landraadvoorzitters op Java en Madoera,' Indisch Genootschap, algemene vergadering (27-3-1900): 153.

51. C.J. Hasselman, 'Pangeran Ario Hadiningrat, een Javaansch pionier,' De Gids (1915) jrg. 79, no. 8: 249-300.

52. Hadiningrat, 'De achteruitgang van het prestige van de inlandse ambtenaren en de middelen om daar verbetering in aan te brengen,' Tijdschrift voor Binnenlandsch Bestuur 3 (1899): 367-385, 380-382.

53. Response to proposal Mounier by C. Th. Van Deventer, Indisch Genootschap, Algemene Vergadering (27-3-1900): 161. 
54. Response to proposal Mounier by Maclaine Pont, Indisch Genootschap, Algemene Vergadering (27-3-1900): 162-163.

55. W. Boekhoudt, 'Een afscheidsgroet aan mijn jongere collega's,' Het Indisch Tijdschrift voor het recht 107 (1-5-1915): 333-334.

56. J. Sibenius Trip, 'Herinneringen uit de Inlandsche Rechtspraak,' Indisch Weekblad van het Recht, no. 2168 (16-1-1905): 1-21.

57. For developments in the Dutch public prosecution service, see A.G. Bosch, 'Het Openbaar Ministerie in de periode van 1811-1838,' in Twee eeuwen Openbaar Ministerie, ed. A.G. Bosch, P.M. Frielink, G.C. Haverkate, M.E. de Meijer, and L. Plas (The Hague: Sdu Uitgevers/Openbaar Ministerie, 2011).

58. Alfons Johan Driessen, Schets der werkzaambeden in strafzaken van den Nederlandsch-Indischenambtenaar van het Openbaar Ministerie (Amsterdam: Brinkman \& Zoon, 1897), 242-253.

59. Van der Kemp, 'De rechterlijke macht in haar streven naar onafhankelijkheid,' 445-481. "O, zeker! Als men over dergelijke hulpmiddelen beschikt, wordt het rechtspreken over den inlander door met het volk onbekende geleerden nog zoo moeielijk niet."

60. Wilhelmus Albertus Johannes van Davelaar, Het strafproces in zaken van misdriff op de terechtzitting van de landraden op Java en Madura vergeleken met de Nederland en Nederlandsch-Indische strafvordering (Leiden: Van Doesburgh, 1884), 39-40.

61. Indisch Staatsblad 1885, no. 81.

62. A.J.C.E. van Heijcop ten Ham, De Berechting van Civiele Zaken en van Misdrijven op de Terechtzitting der Landraden op Java en Madoera (Leiden: Van Doesburgh, 1888), 82.

63. J.J.C. Gaijmans, De Landraden op Java en Madura rechtsprekende in Zaken van Misdrijf (Batavia: Van Dorp, 1874), 34-35.

64. Indisch Staatsblad 1898, no. 66; H.A. Idema Leerboek van het landraad-strafprocesrecht in zaken van misdrijf (Leiden: Brill, 1938), 72.

65. H.A. Idema, 'Indische Juristen Winckel, Piepers, der Kinderen. Iets uit den Strijd om de Legaliteit,' Bijdragen tot de taal-, land- en volkenkunde 100, no. l (1941): 173-233, 195-203.

66. Indisch Familiearchief, The Hague, 8 Familie Hueting. Letter from Cornelis Star Nauta Carsten to his father A.J. Carsten. Blitar, April 7, 1920. 
Open Access This chapter is licensed under the terms of the Creative Commons Attribution 4.0 International License (http://creativecommons.org/licenses/ by $/ 4.0 /$ ), which permits use, sharing, adaptation, distribution and reproduction in any medium or format, as long as you give appropriate credit to the original author(s) and the source, provide a link to the Creative Commons license and indicate if changes were made.

The images or other third party material in this chapter are included in the chapter's Creative Commons license, unless indicated otherwise in a credit line to the material. If material is not included in the chapter's Creative Commons license and your intended use is not permitted by statutory regulation or exceeds the permitted use, you will need to obtain permission directly from the copyright holder.

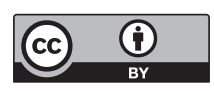

